\title{
Pre-viewing activities and discussions in small groups to improve video comprehension (classroom case study)
}

\author{
K. Karpova \\ National Taras Shevchenko University of Kyiv, Ukraine \\ Corresponding author. E-mail: karpova_k@ukr.net
}

Paper received 12.01.20; Accepted for publication 28.01.20.

\section{https://doi.org/10.31174/SEND-Ph2020-216VIII64-08}

\begin{abstract}
The article aims at investigating how pre-viewing activities as well as discussions in small groups are used to help students with low video comprehension skills to improve them. As a result of low level of competence in video recognition, low achievers have to listen twice or even three times to comprehend the gist of the video recording. In addition to this, these students seem to participate less in classroom debates and have lower level of self-esteem and self-confidence. Thus, the present paper suggests that the usage of activities which precede viewing as well as group discussions can be effective tool to escalate both listening and speaking skills. The present investigation is based on classroom case study that has been conducted during video comprehension classes on the material of Life Upper-Intermediate Student's Book, level B2.
\end{abstract}

Keywords: pre-viewing activity, discussion in small group, low achiever, video comprehension, classroom case study.

Introduction. As one of the main courses at the Department of Foreign Philology in the context of university education, video comprehension activity requires understanding the English language in both monological and dialogical forms. Due to the low language competence some students have difficulties while watching episodes with unknown topics or vocabulary, therefore they need more time and practice in speech recognition. Hypothetically, this problem occurs due to various reasons. Firstly, the students rarely practice video comprehension since this type of activity needs more training to cultivate both listening and watching skills. Secondly, they may not be provided with enough background knowledge before they actually watch the episode. Finally, in the majority of cases students do the assignments after watching individually, so the possibility of interaction is extremely limited. Therefore, the aim of the present study is two-fold: 1). to suggest the usage of pre-viewing activities and discussions in small groups to help low achievers to improve their video comprehension skills, and 2). to gain insights into students' attitudes towards the application of previewing activities and small group discussions.

Methodology of the research. In the course of this classroom-based research general scientific methods such as analysis, synthesis, induction, deduction, and generalization are used to provide a comprehensive review of the literature on the subject under investigation. We also employed the method of qualitative data analysis suggested by A.Burns [5]. The method comprises such five steps of linguistic investigation, as assembling data, coding data, comparing data, interpreting data, reporting the results. The techniques to collect data of the research are tests, observations and interviews.

Review of publications on the subject. For the time being, multimedia technologies are prevailing in all spheres of life and human activities, including education. For this reason multimedia have a potential to reshape and add a new dimension to the continuous process of acquiring knowledge. Recently, there has been growing interest in studying the application of multimedia in the sphere of education. According to Balyk \& Yanyshyn, "education these days needs tremendous change as today's students belong to generation $\mathrm{Z}$, which totally depends on the Internet and multimedia technologies" [1, p. 169]. The usage of up-to-date computer innovations and multimedia technologies provides teachers with completely new opportunities in organizing the process of mastering any subject, including foreign languages. The introduction of multimedia into the process of teaching foreign languages is focused on significantly improving communicative competence under the condition of absence of natural environment. For this reason, the role of multimedia, namely audio and video content, cannot be overestimated.

It must be emphasized that, many foreign scholars have addressed the issue of using video materials at language classes, including R. Berk [2], J. Brophy [4], I. Cakir [6], J. Sherman [13], J. Wang \& K. Hartley [14], K. Woottipong [15] etc. Among Ukrainian scientists who made the great contribution into the study of the role of multimedia resources in teaching English the following must be mentioned: N. Balyk \& N. Yanyshyn [1], V. Chmel [7], U. Naumenko [10], H. Potochniak [11] and others. Numerous investigations on the application of videos at foreign language classes prove their effectiveness, consequently this activity is highly recommended on an ongoing basis [2, 8, 14].

Results and Discussion. Over the past decade video comprehension as an audio-visual educational material has become an efficient classroom activity which stimulates visual and auditory codes, develops attention spans, trains memory, helps the students to master communicative skills, accordingly, enhances their self-confidence and self-esteem. Currently ever-growing percentage of teachers are supporting the benefits of this tool and incorporating it into their curriculum, as the use of videos stimulates such cognitive processes as thinking, reasoning, problem-solving, decision-making, and creating. It is a common practice to watch video episodes as the final stage in studying the topic, when students have already accumulated the basic knowledge on the subject.

It should be born in mind, that video comprehension activity includes pre-viewing, while-viewing (viewing itself) and post-viewing assignments. Of three aforecited video comprehension stages, pre-viewing is of utmost importance, because in this stage the teacher prepares the students for what they will watch and what they are expected to do. The success of the activity which precedes watching itself depends on the ability of the teacher to 
activate the students' background knowledge and direct them to achieve the goal. Hence, pre-viewing is an effective tool to generate interest, build confidence and facilitate further understanding.

Special attention must be paid to the preparation of the students for watching in order to diminish the difficulties that they may face. The following techniques are commonly used at this stage: revision of vocabulary and key points of the topic studied previously, then, discussion of some questions may be useful as a warm-up activity. These assignments enrich students' vocabulary on the topic, improve their learning and professional skills and develop their language competence.

The main challenge of present research is that some students have difficulties understanding video materials delivered at class. As a result, they tend to be passive in the further learning activity. In our research we rely on the following types of pre-viewing activities: answering the questions, vocabulary discussions, brainstorming of personal experience, content prediction, relevant reading, knowledge quiz, and so on. Afterwards the students watch the episode for general information, and then watch it one more time to get specific information. Later on, class discussion is conducted for the post-viewing activities, in which each group presents the results or sums up the gist of the video episode.

Within the framework of our experiment, to exemplify the use of pre-viewing activities and discussion in small groups under consideration we have chosen the video called "History of Film" from the course book Life Upper-Intermediate Student's Book, Unit 2 [9]. We begin by suggesting the students the following pre-viewing activities:

Activity 1. Brainstorm your ideas about cinematography and the process of making a movie. Share your ideas with your partner.

Activity 2. Before watching the video episode, look at the photo and discuss the following questions:

1.1. What do you think the man in the photo is doing?

1.2. When do you think the photo was taken?

1.3. Why do you think the photo is made up of several images?

Activity 3. Before watching the video episode, look at the pictures, compare and contrast them.

You can use Useful Language Section while doing this activity: both pictures show; picture $1 \ldots$ but picture 2 ; picture 1 , on the other hand picture 2 ; although picture $1 \ldots$, picture 2 ; picture 1 in contrast to picture 2 ; pictures 1 and 2 are similar/different, because... .

Activity 4. These words are mentioned in the video recording. Consult the dictionary to match them with their definitions:

\begin{tabular}{|l|l|}
\hline \multicolumn{1}{|c|}{ WORD } & \multicolumn{1}{c|}{ DEFINITION } \\
\hline arcade & an important historical moment \\
\hline entrancing & $\begin{array}{l}\text { an old style of drama that has } \\
\text { exaggerated emotion and action }\end{array}$ \\
\hline landmark & showing film on a screen \\
\hline melodrama & $\begin{array}{l}\text { a passage with a roof and a shop } \\
\text { on both sides }\end{array}$ \\
\hline nickelodeon & fascinating \\
\hline projection & a type of variety show \\
\hline vaudeville & an old type of cinema \\
\hline
\end{tabular}

Activity 5. You are going to watch a video about the history of film. Tick the things and people you think you might see in the video:

5.1. Actors arriving at an award ceremony

5.2. The Arctic

5.3. Charlie Chaplin

5.4. Documentary film

5.5. A scene from an animated film

5.6. A scene from a cartoon

The next step is to use the technique of small group discussions as a post-viewing assignment, which serve intellectual (awareness of the variety of opinions), emotional (personal involvement in the discussion), and social (cohesion and rapport to each other) purposes. It must be mentioned, that group discussion is a form of cooperative learning in which students are divided into small groups to discuss and find solution to the problem. Such groups enable its members to have closer interaction and share ideas so that low achievers can learn more from those with high command of English. According to M. Reineke, the advantage of small group discussion is that it creates positive interdependence, as group members "sink" together; face-to-face interaction and advocacy as the students learn together; and individual accountability, as each group member has a responsibility to contribute to the group and do their "fair share"[12]. Relying on the opinion of E. Brewer [3, p. 23], we define the main purpose of group discussion as contributing and circulating information on a particular topic as well as analyzing and evaluating information in order to reach an agreement on general conclusion. Our classroom case study presupposes the following activities in small groups:

Activity 1. Work with a partner and answer following questions:

1.1. What kind of films do you prefer?

1.2. Do you enjoy watching documentaries? Why? Why not?

1.3. How important is film industry in your country?

Activity 2. Work in groups of two. Look at the definitions of film industry. Get ready to discuss them in groups with your partner:

1.4. The entertainment industry involved in producing and distributing movies

1.5. The technological and commercial institutions of filmmaking

Activity 3. Work in groups of three. First read famous quotes 1-5 and decide individually whether you agree or disagree with them. Think about examples you can use to support your points of view.

You can use Useful Language Section while doing this activity: I agree/disagree/don't agree; I believe it's false; I don't think it's true; I think it depends:

3.1. For me, the cinema is not the slice of life, but a piece of cake (Alfred Hitchcock)

3.2. I think cinema, movie, and magic have always been closely associated (Francis Ford Coppola)

3.3. At the cinema, we do not think, we are thought (Jean-Luc Howard)

3.4. Cinema is a matter of what is in the frame and what is out (Martin Scorsese)

3.5. Self-plagiarism is style (Alfred Hitchcock)

Activity 4. Role-play "An interview with a famous actor or actress" 
Student 1. Imagine you are a famous Hollywood actor or actress.

Student 2. Imagine you are paparazzi. You are going to interview a famous Hollywood actor. Act out the interview, then change the roles and act out it again.

In the process of our classroom case study positive results of the experiment have been revealed. First and foremost, video comprehension class seemed to be more interactive as each member of the group shared his/her own opinions and participated in group discussions actively. Second, student with low level of language competence were given the chance to boost their confidence and self-esteem thanks to their constant participation in class conversations. Owing to the implementation of brainstorming activities into the educational process, group members shared their knowledge and experience on the topic under consideration. Group discussions which preceded class discussions made low achievers better prepared to contribute to the discussion as they were more confident at the stage of group discussion. Finally, discussions in small groups helped to decrease tension and create favorable atmosphere. When working in groups the students collaborated in order to reach consensus on the discussed issues. All things considered, while interviewing the students about the use of pre-viewing and postviewing activities, we have received honorable mentions only.

Conclusions. Taking everything mentioned above into account, it is vital to enhance students' communicative competence via implementing pre-viewing activities and discussions in small groups into the teaching process. The use of the aforesaid techniques is believed to improve the quality of teaching English at the Department of Foreign Philology at video comprehension course. The attempted investigation proved to be a success as the involvement of the students with low level of linguistic competence and watching skills multiplied because they gained more confidence in class debates.

\section{RERERENCES}

1. Balyk, N.R., Yanyshyn, N.M. Vykorystannia video v osvitniomu protsessi // Suchasni informatsiini tekhnologii ta innovatsiini metodyky navchannia: dosvid, tendentsii, perspektyvy, 2019. (3). P. 169-172.

2. Berk, R.A. Multimedia teaching with video clips: TV, movies, YouTube, and $\mathrm{mtv} U$ in the college classroom // International Journal of Technology in Teaching and Learning, 2009. 5 (1). P. 1-21.

3. Brewer, E.W. 13 proven ways to get your message across. The essential reference for teachers, trainers, presenters, and speakers. Corwin Press INC, 1997.

4. Brophy, J. Using video in teacher education. Oxford, UK: Elsevier, 2004.

5. Burns, A. Collaborative action for English language teachers. Cambridge: Cambridge University Press, 1999.

6. Cakir, I. The use of video as an audio-visual material in foreign language teaching classroom // The Turkish Online Journal of Educational Technology, 2006. 5 (4). P. 67-72.

7. Chmel, V.V. Use of video materials in teaching English for specific purposes // Advanced Education, 2015. Is. 4. P. 5659.

8. Cummins, P. Video and the French teacher // French Review, 1989. (62). P. 411-426.

9. Dummett, P., Hughes, J., Stephenson, H. Life. UpperIntermediate. Student's Book. Cengage Learning, 2016.

10. Naumenko, U.V. Innovatsiini medody navchannia angliiskoi movy u vyshchii shkoli v umovakh modernizatsii // Molodyi Vchenyi , 2018. 3.1 (55.1). P. 118-122.

11. Potochniak, H.I. Vykorystannia videoblohiv na praktychnykh zaniattiakh $\mathrm{z}$ angliiskoi movy // Molodyi Vchenyi , 2019. 4.2 (68.2). P. 182-185.

12. Reineke, M. Guidelines for small group discussions. Retrieved from https://www.uni.edu/reineke/guidelin.htm

13. Sherman, J. Using authentic video in the language classroom. Cambridge: Cambridge University Press, 2003.

14. Wang, J. \& Hartley, K. Video technology as a support for teacher education reform // Journal of Technology and Teacher Education, 2003. 11 (1). P. 105-138.

15. Woottipong, K. Effect of using video materials in the teaching of listening skills for university students // International Journal of Linguistics, 2014. 6 (4). P. 200-212. 